\title{
Presentación
}

Teorías de la cultura, tiempo histórico, memorias políticas y usos públicos del pasado, e identidades y construcciones narrativas son los temas que componen este número de Historiografías. Se trata de asuntos que forman parte indiscutible del debate historiográfico internacional, y que la revista viene recogiendo desde que lanzara su primer número, hace exactamente cinco años. Esta dimensión global está avalada, además, por la presencia de un consejo científico en el que se cuentan, aparte de profesores de la universidad española dedicados a la teoría y el estudio de la historiografía, conocidos expertos de universidades francesas, británicas, latinoamericanas y de los Estados Unidos.

En esta entrega, hemos de lamentar la pérdida del profesor don Elpidio Laguna Díaz, miembro del citado consejo, quien falleció el 25 de enero pasado. A él va dedicado el contenido de este número 11. El profesor Laguna Díaz era un hispanista especialmente apreciado en la comunidad latina y puertorriqueña de los Estados Unidos. Había nacido junto a la capital de ese Estado, San Juan, en Río Piedras, y desarrollado su carrera de profesor desde 1972 en el Department of Classical \& Modern Languages and Literatures de Rutgers, la Universidad estatal de Nueva Jersey en el campus de la ciudad de Newark, especializándose en literatura e historia españolas y latinoamericanas. Sus numerosos discípulos, que hoy dan clases de lengua y cultura española en Universidades e Institutos de segunda enseñanza de ese país, coinciden en resaltar su enorme dedicación a las clases y sus amplios puntos de vista, porque el profesor Laguna Díaz reunía algunas peculiaridades que le condujeron a apreciar especialmente la teoría cultural y la reflexión historiográfica.

Tuve la ocasión de conocerlo personalmente y de ser acogido generosamente en su Departamento por él y por la profesora, y directora (Chair) del mismo, la doctora Asela Rodríguez, su esposa, y puedo atestiguar esa impresión que tenían sus discípulos: el profesor Laguna Díaz, además de una amplia cultura que abarcaba tanto la historia de España como la de los Estados Unidos, era un apasionado defensor de lo hispánico (que para él se complementaba con los estudios portugueses y brasileños), así como del interés por la teoría historiográfica. En realidad ambos aspectos iban ligados, pues Elpidio Laguna era un hispanista militante que concebía lo hispano, en compañía de lo luso, como una forma de cultura en el amplio sentido del término (ideas, creencias, pasado, memoria, opinión pública, etc.). Buen conocedor de España -había vivido en Salamanca y dirigió varios programas de verano académicos, de estudios y visitas, desde Rutgers-, se dedicó desde su puesto de profesor a difundir la identidad y cultura hispano-lusas y los que consideraba sus principales vehículos de expresión: el español y el portugués. Su defensa de lo hispánico le llevó al interés por la teoría de la cultura y de la historiografía. En Historiografías publicó, en el número 3 de enero-junio de 2012 (pp. 8-25), un texto de análisis de teorías de la cultura, muy significativo y recomendable, titulado “Globalización, Civilización, Americanización: cabos sueltos”, en el que muestra su concepción del hispanismo como fenómeno cultural y sus vastos conocimientos.

No es casual pues que el doctor Elpidio Laguna también formase parte del Consejo Científico de "Historia a Debate" fundado por el profesor Carlos Barros en 1999 -foro que ha hecho sin duda una notable labor para acercar visiones de la 
historiografía en el campo hispánico (de España y de los países de Latinoamérica) con su conocido Manifiesto-. Además, Elpidio Laguna fue vicepresidente de la International Society for the Comparative Study of Civilizations (1998-2004), en la etapa de mandato de Wayne M. Bledsoe, hoy profesor emérito de la Missouri University of Science and Technology.

La teoría y la historia comparada de las civilizaciones tiene un origen remoto europeo, como se puede leer en el sitio oficial de la International Society for the Comparative Study of Civilizations, que presume de haberse fundado en Salzburg (Austria) en 1961 en una reunión a la que asistió nada menos que el famoso historiador británico Arnold J. Toynbee. Pero el lugar donde creció dicha especialidad fue en los Estados Unidos a partir de los años setenta; primero porque fue allí y en esa década cuando sus componentes multiculturales comenzaron a diversificarse -una vez que la minoría afroamericana conquistó sus derechos civiles básicos-, y segundo porque fue en sus universidades donde han arraigado autores que se han adentrado en la teoría marxista más heterodoxa así como en otras teorías digamos postmodernas. Para el profesor Elpidio Laguna, como puede observarse en el artículo publicado por Historiografías, el estudio de la teoría de las civilizaciones servía para entender los efectos de la globalización y para indagar el puesto que ocupaba la cultura hispánica en ese contexto.

El presente número de Historiografías abarca, como decíamos, una temática amplia, un repertorio que, además de tratar de teoría cultural, se extiende a la historiografía y las memorias de un amplio espacio geográfico y cronológico que va de España a Argentina, pasando por México, y que abarca desde temas recientes, como la transición española, hasta historiografía medieval.

Como es sabido, la década de los setenta y ochenta, una vez llegaron a su fin los procesos de descolonización, el imperio soviético inició su retroceso económico y en Occidente se comenzó a enaltecer el neoliberalismo, asistió al impulso o la renovación de la teoría cultural. Esta renovación, combinada con afanes memoriales (o mejor dicho, capaz de integrar la reflexión sobre la memoria), no se ha detenido. Las citadas décadas no solo fueron la época de puesta de largo de los estudios sobre el postmodernismo, gracias en particular a los escritos de Fredric Jameson (los ochenta en particular), sino también las que contemplaron las primeras reformulaciones del concepto de modernidad.

El profesor de la Universidad del País Vasco, José Javier Díaz Freire, abre el apartado de "Historia y Teoría” con "Tiempos de modernidad, a propósito de Marshall Bergman”. En él rescata un texto clásico, que estuvo en el centro de los debates de los años inmediatamente anteriores a la caída del Muro y antes de que la globalización diese su salto definitivo, algunos de cuyos capítulos se remontan a los setenta. Se trata de la obra del pensador marxista norteamericano Marshall H. Berman, profesor de Ciencia Política y Urbanismo en el City College de Nueva York fallecido hace tres años: All that is Solid Melts into the Air. The Experience of Modernity, lanzada en 1983 reeditada en 1988, y publicada en español ese año.

Berman, acaso gracias a su marxismo heterodoxo, forma parte de una tradición filosófica, mucho más amplia, desde Martin Heidegger hasta Walter Benjamin, que 
durante el siglo XX ha criticado el concepto hegeliano de historia y de tiempo, o en su caso el llamado marxismo economicista. La aportación principal de Berman es, como señala el profesor Díaz Freire, el mostrar que la idea de "modernidad" (y por extensión las de "modernización” y “modernismo") puede ser una noción "líquida”, esto es, sujeta a un tiempo heterogéneo, lo que equivale a atribuirle parecida propiedad a la que algunos autores reclaman para la categoría de la postmodernidad (por ejemplo, Zigmunt Bauman cuando usa, con cierto equívoco, el término "modernidad líquida” para referirse a lo postmoderno). Como dice el profesor Díaz Freire, si queremos que el concepto de modernidad tenga valor para la investigación social hoy -“que se levante el estado de sitio” sobre este concepto-, no hay más remedio que abandonar también la idea de un tiempo homogéneo. Las respuestas que dieron Perry Anderson y Peter Osborne -este influido por la reflexión koselleckiana sobre las temporalidades- a Berman, glosadas con habilidad en este artículo, son una buena muestra de las posibilidades de actualización de los citados conceptos de modernidad, modernización y modernismo.

El resto de los artículos de este número de Historiografías versa sobre memoria, y sobre identidades nacionales y sus relatos, en relación con la escritura de la historia.

El texto de Díaz Freire da paso al de los profesores mexicanos Oscar Fernando López Meraz y Diana Villegas Loeza quienes abordan un tema que ha jugado y juega un papel decisivo en los cambios de la historiografía de los años ochenta para acá -con la obligada referencia, que los citados autores hacen, a los pioneros Benedict Anderson y Eric J. Hobsbawm-, como es el de las identidades nacionales. El texto se titula, "Discurso científico, profesionalización histórica e identidad nacional mexicana". Ya hemos tratado esta línea en Historiografías a propósito, por ejemplo, del tema del "bretonismo político" (publicado en el número 5). En este caso, que se refiere a la identidad mexicana, el texto añade el tema de la cuestión del nacimiento y desarrollo de la profesión de historiador en el país azteca desde el siglo XIX -aunque la primera Historia de México, ya con una idea de identidad nacional, la publica en el XVIII el jesuita Francisco Javier Clavijero-. El asunto se halla, señalan los autores, estrechamente enlazado con la difusión del sentimiento de pertenencia a esa "comunidad imaginaria", que reclama futuro y pasado, como es el correspondiente a la idea de nación moderna. De entre los principales elementos de la mexicanidad, López Meraz y Villegas ponen el acento en la figura del indio, que permite remontar el pasado del país hasta tiempos prehispánicos. Así, desde Carlos María Bustamante, político periodista, historiador y líder de la independencia del Imperio español a comienzos del siglo XIX, hasta los más recientes análisis, la figura del indio sigue bebiendo del estereotipo que, en su momento, dibujó el franciscano y cronista de Indias, Bernardino Sahagún en el siglo XVI. La consecuencia que se obtiene de semejante uso no por obvia es menos importante: la historia de la historiografía, de las identidades y de la memoria tienen un valor desmitificador, y en este caso sirven para mostrar hasta qué punto las fuentes, lejos de ser repositorios neutrales o inocentes, constituyen parte del ambiente social y cultural en el que nacieron, y así deben ser tratadas.

El trabajo de la profesora argentina María del Mar Solís Carnicer, “El pasado argentino en disputa. Peronismo y antiperonismo en la interpretación de la historia de la provincia de Corrientes”, que aparece en tercer lugar, nos lleva a un terreno vecino que también Historiografías ha tratado en anteriores entregas: el de las luchas de memorias 
(en el número 8), y el del papel de los héroes en la construcción memorial y en la historiografía nacional (en el número 10). El trabajo de la profesora Solís Carnicer estudia las peculiaridades que presenta el debate sobre los usos públicos del pasado en la provincia de argentina de Corrientes. Esta provincia periférica situada en el Noreste del país limitando al norte con Paraguay, señala la autora, contaba con su propio panteón político de héroes de la independencia, e incluso había “regionalizado" la figura del Libertador, de José de San Martín. La llegada del peronismo a finales de la década de los cuarenta -con un planteamiento revisionista de la historia argentina y una visión distinta de la política- y la conmemoración del centenario de la muerte de El Libertador en 1950 trastocará dicho panteón y afectará a sus héroes locales, quienes concitaban hasta entonces una razonable unanimidad. El presente trabajo da una imagen muy completa de cómo estaban configurados los estudios históricos en la citada provincia, pero, como señala la autora, la disputa memorial traída por el peronismo nada tiene que ver con las actuaciones en el pasado de los mentados personajes; está relacionada, más bien, con "los intereses del presente".

Cierra la sección de “Historia y Teoría” el trabajo del historiador gallego Bruno Padín Portela: "Un episodio en la construcción narrativa de la Historia de España: los traidores y la 'pérdida de España”". Este estudio continúa dentro del ámbito de las identidades nacionales y las memorias (la memoria cultural podríamos decir aquí). En este caso, el texto examina el estereotipo o estructura narrativa representada en un conocido episodio que dejó su huella en las Historias de España durante siglos, desde la Historia General de España del Padre Mariana publicada a finales del siglo XVI, hasta enciclopédica Historia de España Menéndez Pidal editada a lo largo del siglo XX, pasando por la de Modesto Lafuente del siglo XIX: la "tradición goticista" que atribuye la desaparición de reino visigodo de Toledo a la "traición del Conde don Julián”, quien, para vengar la violación de su hija a manos de don Rodrigo, se alió con los judíos y provocó la llamada "pérdida de España”.

Para examinar la relevancia y permanencia de este relato, el autor procede a su “deconstrucción” siguiendo varias líneas que, a buen seguro, interesarán al especialista en historia de la historiografía: en primer lugar, los orígenes de dicho relato con el estudio de las versiones cronísticas y sus variantes, y en segundo lugar, la relevancia inicial de mismo a través de dos nociones: por un lado, el concepto de "traición" en el derecho romano y en los códigos germánicos, y, por otro, la idea del deseo sexual según el texto contemporáneo de las Etimologías (siglo VII) de San Isidoro. Aquí se podría volver a suscribir lo que decía la profesora Solís Carnicer en su artículo: el citado relato dice más de las vicisitudes de la memoria cultural y del género historiográfico durante siglos que del fenómeno real de la llegada de los musulmanes a la península ibérica en el siglo VIII. Para demostrarlo, el autor se detiene a examinar también lo que los especialistas han escrito sobre el citado fenómeno, desde el conocido especialista en el reino visigodo y profesor de Nottingham ya fallecido, Edward A. Thompson, hasta autores recientes como Alejandro García Sanjuán, pasando por el norteamericano Norman Roth o los españoles Pedro Chalmeta y Luis Agustín García Moreno.

En el apartado "Varia historiográfica” ofrecemos esta vez dos artículos muy diferentes aunque unidos por el temas de las memorias y las identidades. 
El primero de ellos es el del profesor Raimundo Cuesta Fernández, que lleva por título "La normalización historiográfica y la pérdida de la inocencia. Reflexiones acerca de algunas tesis del historiador Santos Juliá”. Este texto es un comentario crítico del libro del profesor Juliá, Hoy no es ayer. Ensayos sobre la España del siglo XX (Barcelona, RBA, 2010), que recoge escritos de este autor publicados entre 1996 y 2010 que reflejan su notable trayectoria historiográfica, intelectual y política (la intervención tuvo lugar en el Aula de Debate "La España Actual” de la Universidad de Salamanca en marzo de 2015, y contó con la asistencia del propio autor del libro).

El profesor Santos Juliá, uno de los más reconocidos historiadores del actual panorama español, es un autor conocido en Historiografías, que publicó una entrevista suya en el número 3 en la que este abordaba temas como la situación actual de la historiografía española, la influencia del postmodernismo en la historiografía y la memoria de la guerra civil española. El artículo del profesor Cuesta Fernández, más allá de las críticas que formula al citado libro, tiene una interesante propiedad que va también más allá de la polémica entre dos historiadores: da una idea bastante aproximada de cuáles son en España las discusiones claves que afectan al uso público del pasado. El artículo en cuestión aborda los siguientes temas: a) cómo valorar globalmente los cambios políticos y sociales acontecidos en España desde el siglo XIX: ¿fracaso, normalidad, otras alternativas?; b) cómo ha cambiado actualmente la percepción de la transición política española y cómo debe afectar ese cambio de las memorias a los historiadores; y c) qué papel juega la actual cultura de la memoria y cómo afecta a la historiografía en general y a la valoración de la memoria y de la historia de la guerra civil española en particular. Un artículo que, a buen seguro, no dejará indiferentes a los lectores.

El segundo de los textos de "Varia historiográfica”, del especialista argentino profesor Patricio Iván Pantaleo, tiene, en el contexto de la revista, una pretensión mitad informativa mitad interdisciplinaria. Forma parte del interés de Historiografías en dar a conocer especialidades o áreas que suelen ser relativamente minoritarias. El trabajo se titula "Mircea Eliade y la historia de las religiones. Lecturas y aportes para una difusión historiográfica”. En este texto, el profesor Pantaleo hace un repaso de los principales autores del campo de la historia de las religiones (lo cual incluye bibliografía latinoamericana) y se detiene en la vida y obra de uno los principales representantes del mismo: el rumano Mircea Eliade, una figura intelectual que, como dice el autor, fue mucho más que un historiador de las religiones. Retengamos la siguiente idea del artículo, que fue glosada por Carlo Ginzburg en sus comentarios sobre el rumano, y que muestra lo compleja que puede ser la trayectoria intelectual, así como el juego de las identidades y las memorias culturales: la obra de Eliade tiene un carácter ambivalente. Eliade militó en la extrema derecha rumana durante la época de entreguerras y la Segunda Guerra Mundial, pero fue capaz de hacer compatible dicha militancia con el orientalismo (viajó a la India y se vio fuertemente influido por sus culturas), lo que le llevó al terreno de la historia de las religiones. Ginzburg hace el siguiente comentario de esa ambivalencia: "ha concluido la época de las simples dicotomías”. 
El número concluye como de costumbre con la sección de Crítica: ensayos bibliográficos y reseñas. En este caso hemos incluido comentarios de libros recientes de historiografía española, hispanismo, memoria, epistemología, teoría de la historiografía y estudios sobre la Antigüedad.

\section{Gonzalo Pasamar}

\section{Presentation}

Theories of culture, historical time, political memories, public uses of the past, and identities and narrative constructions make up the main topics of this issue of Historiografías. They are themes that have an indisputable role to play in the international historical debate, which the journal has attempted to mirror ever since its first issue was published five years ago. In addition to Spanish professors devoted to the theory and study of historiography, this global aspect is also endorsed by the work of an advisory board that includes well-known experts from French, British, Latin-American, and US Universities.

In this instalment it is with deep regret that we are obliged to inform our readers of the loss of Professor Elpidio Laguna Díaz, member of the board, who passed away on 25 January. Issue number 11 pays tribute to him. Professor Laguna Díaz was a Hispanist who was much admired in the Latin and Puerto Rico community in the US. He was born near the state capital of San Juan, in Río Piedras, and developed his career as a professor from 1972 onwards at the Department of Classical \& Modern Languages \& Literatures on the Newark campus of Rutgers, The State University of New Jersey, becoming a specialist in Spanish and Latin-American literature. His numerous disciples, who are giving classes in Spanish language and culture at universities and high schools in this country, coincide in highlighting his broad mind and tremendous commitment to his classes, as Professor Laguna had a combination of special traits enabling him to pay special attention to both cultural theory and historical reflection.

I had the chance to meet him personally and to be warmly welcomed at his Department both by Professor Laguna himself and also by his wife - and Chair of the Department - Professor Asela Rodríguez. I can also vouch for his disciples' impressions: in addition to having a vast culture that ranged over both the history of Spain and the US, Professor Laguna Díaz was a passionate advocate of Hispanic Studies (which for him were complemented by Portuguese and Brazilian studies) as well as cultivating an interest in historiographic theory. In fact, both aspects were connected, since Elpidio Laguna was a militant Hispanist who regarded Hispanic studies, along with the Portuguese component, as being a form of culture in the widest sense of the term (ideas, beliefs, the past, memory, public opinion, etc.). A good connoisseur of Spain - he had lived in Salamanca and conducted several summer academic programmes of study and visits from Rutgers - and worked hard from his position as a professor to disseminate the Hispanic and Portuguese identity and culture and what he saw as their principal vehicles of expression: the Spanish and Portuguese languages. His defence of Hispanic studies led him to develop an interest in the theory 
of culture and historiography. In Historiografías he published a paper in Issue number 3 of January-June 2012 (pp. 8-25) that was very significant and highly recommendable analysing the theories of culture, entitled: "Globalization, Civilization, and Americanization: Loose Ends". Here he presented his view of Hispanism as a cultural phenomenon, as well as his vast knowledge of the subject.

Thus, it is not surprising that Dr Elpidio Laguna also formed part of the advisory board of "History under Debate" founded by Professor Carlos Barros in 1999.This is a discussion forum that has undoubtedly played an outstanding role in bringing us into closer contact with historiographic points of view within the Hispanic field (both in Spain and in Latin American countries) with its well-known Manifesto. Moreover, Elpidio Laguna was Vice-president of the International Society for the Comparative Study of Civilizations (1998-2004), during Wayne M. Bledsoe's term, who is emeritus professor in the Missouri University of Science and Technology today.

The comparative history of civilizations has distant European origins, as one can read on the official website of the Society for the Comparative Study of Civilizations, which was founded in Salzburg (Austria) in 1961 at a meeting attended by none other than the famous British historian Arnold J. Toynbee. But the place where this speciality really came into its own was the USA from the 1970s onward, firstly because it was then and there that its multicultural components began to diversify - once the AfroAmerican minority conquered their basic civil rights - and second, because it is at their universities where some authors had rooted and delved into the most unorthodox Marxist theory as well as other theories that might be referred to as post-modern. To Professor Elpidio Laguna, as one can see in the paper published in Historiografías, the study of the theory of civilizations facilitated our understanding of the effects of globalization and for exploring the place Hispanic culture occupies in this context.

This issue of Historiografías, as we said, covers a broad theme, a repertoire which, besides dealing with cultural theory, ranges over the historiography and memories of a vast geographical and chronological space. It goes from Spain to Argentina, including Mexico, and embraces both recent topics such as the Spanish transition and medieval historiography.

As is well-known, once the processes of decolonization had drawn to a close, the Soviet empire had embarked on its economic retrogression, and neoliberalism had begun to develop in Western countries, the decades of the 1970s and 1980s witnessed the stimulus or renovation of cultural theory. This renovation, combined with interest in memory (or rather, integrating reflection on memories), had by no means ceased to exist. The decades alluded to were not only the period heralding the debut of postmodernist studies, thanks in particular to Fredric Jameson's writings (particularly in the 1980s), but also contemplated the first re-working of the concept of modernity.

José Javier Díaz Freire, Professor of the University of the Basque Country (Spain), opens up the section of "Historia y Teoría" with "Times of Modernity. Regarding Marhall Berman”. In this paper he retrieves a classic text, which was at the core of the debates on the eve of the fall of the Berlin Wall and before globalization took a leap forward, with some of the chapters going back to the 1970s. It is the work of the US Marxist thinker Marshall H. Berman, professor of Political Science at City 
College in New York, who passed away three years ago: All that is Solid Melts into the Air. The Experience of Modernity, released in 1983, reedited in 1988, and also published in Spanish that year.

Berman, (possibly on account of his heterodox Marxism) takes part in a much wider philosophical tradition involved, from Martin Heidegger to Walter Benjamin, in criticizing the Hegelian concepts of history and time, or even the "economistic" form of Marxism, throughout the $20^{\text {th }}$ century. Berman's main contribution, according to Professor Díaz Freire, is to show that the idea of "modernity" (and therefore those of "modernization" and "modernism") is capable of transforming itself into a "liquid notion", namely an idea subject to a heterogeneous time - a property that some writers also claim for the category of post-modernity (for instance, Zygmunt Bauman when he uses, the term of "liquid modernity", in an ambiguous fashion, to refer to the postmodern era). According to Professor Díaz Freire, if we really want the concept of modernity to have validity for social inquiry today - "the siege should be lifted" with respect to this concept - then we have no other choice but to also abandon the idea of a homogenous time. The answers given to Berman by Perry Anderson and Peter Osborne (the latter being influenced by Koselleck's reflection on temporalities), skillfully commented on in this article, are a good example showing what the possibilities of updating the aforesaid concepts of modernity, modernization, and modernism really entail.

The other articles in this instalment revolve around memory, and national identities and their narratives, in relation to the writing of history.

Díaz Freire's paper is followed by that of the Mexican Professors, Oscar Fernando López Meraz and Diana Villegas Loeza, in which they address a topic such as national identities, which has played a critical role in historiographic development from the 1980s onwards - with the obligatory reference to pioneers Benedict Anderson and Eric J. Hobsbawm. The title of the text is "Scientific Discourse, Historical Profession, and the Mexican National Identity". Historiografias has already taken this line, for example, with respect to the topic of "political Bretonism" (published in Issue number 5). In this case, which refers to Mexican identity, the article adds the topic of the emergence and development of the historian's profession in the Aztec country since the $19^{\text {th }}$ century (although the first History of Mexico to touch on an idea of national identity was published by the Jesuit Francisco Javier Clavijero in the $18^{\text {th }}$ century). According to the authors, the topic is closely related to the dissemination of the feeling of belonging to this "imaginary community", which lays claim to both past and future, as is the case with the concept of a modern nation. Among the main elements of Mexicanity, López Meraz and Villegas highlight the figure of the Indian, which enables them to go back to Pre-Hispanic times. In this way, from Carlos María Bustamante, politician and journalist, historian and leader of Mexican Independence from the Spanish Empire at the beginning of the $19^{\text {th }}$ century, to the most recent analysis, this figure continues to fuel the stereotype fashioned by the Franciscan and Chronicler of the Indies, Bernardino Sahagun, in the $16^{\text {th }}$ century. As a consequence of this use, perhaps obvious but no less important, is the fact that the history of historiography, identities, and memory has a demystifying function. In this case, this means showing to what extent the sources - far from neutral and naïve - form part of the social and cultural fabric from which they emerged, and should be treated as such. 
The third paper, by Argentine Professor María del Mar Solís Carnicer, entitled "The Argentine Past in Dispute. Peronism and anti-Peronism in the Interpretation of the History in the Province of Corrientes”, leads us to a neighbouring field, focused on by Historiografias in previous instalments: namely, that of memory struggles (Issue number 8), and the role of heroes in the construction of identities and national memories (Issue number 10). Professor Solis Carnicer's work examines the peculiarities of the debate on the political uses of the past in the Argentine province of Corrientes. This peripheral north-eastern province bordering on Paraguay to the north, had, as the author points out, its own political pantheon of heroes who had fought for its Independence, and even depicted José de San Martín, the national Libertador, as a regional figure. The coming of Peronism in the late 1940s - with a revisionist view of Argentinian history and a different appreciation of politics - as well as the commemoration of the centenary of the Libertador's death, disrupted the pantheon and affected its local heroes, who, until then, had always generated a reasonable degree of unanimity. This work gives a complete image of how historical studies were set up in that province, but as the author says, the memory dispute brought about by Peronism had nothing to do with the past actions of the aforementioned figures, but was instead more related to "interests in the present”.

The Section "Historia y teoría" closes this issue of the journal with the work of the Galician historian Bruno Padín Portela: “An Episode in the Narrative Construction of the History of Spain; The Traitors and the "Loss of Spain'”. The study continues to fall within the field of national identities and memories (the cultural memory, we might say in this case). The paper examines the stereotype or narrative structure represented in a well-known episode which marked the Histories of Spain for centuries, from Father Mariana's Historia General de España published at the end of the $16^{\text {th }}$ century, to the encyclopaedic Historia de España Menéndez Pidal, released throughout the $20^{\text {th }}$ century, including Modesto Lafuente's in the $19^{\text {th }}$ century: the Gothic tradition, which attributes the fall of the Visigothic Kingdom of Toledo to “Count Julian's betrayal”, who, so as to revenge his daughter's rape at the hands of don Rodrigo, allied himself with the Jews and brought about the so-called "loss of Spain".

In order to examine the relevance and permanence of this narrative, the author deconstructs it along several lines which will surely attract the attention of the expert in the history of historiography: first, the origins of this story with the study of the chronicle versions and their varieties; second, the initial relevance through two notions: on the one hand, the concept of betrayal in Roman and German Law; on the other hand, the idea of desire as it was regarded by the contemporary text of Las Etimologías ( $^{\text {th }}$ century) by Saint Isidore. Here one could subscribe again to what Professor Solís says in her article: the aforementioned narrative reveals more about the vicissitudes of cultural memory and of historical genre throughout the centuries than about the true coming of Muslims to the Iberian Peninsula in the $8^{\text {th }}$ century. To show this to indeed be the case, the author also stops to examine what experts have written on this historical phenomenon, from the well-known specialist on the Visigothic Kingdom and professor of Nottingham, Edward A. Thompson, now deceased, to recent authors such as Alejandro García Sanjuán, including the US Norman Roth and the Spanish Pedro Chalmeta and Luis Agustín García Moreno. 
In the Section "Varia historiográfica" this time we offer two articles that are very different while both sharing the same topic of memories and identities.

The first is that of Professor Raimundo Cuesta Fernández, entitled "Historiographic Normalization and the Loss of Innocence: Reflections on some Theses of the Historian Santos Juliá”. This text is a review of Professor Juliá's book Hoy no es ayer. Ensayos sobre la España del siglo XX (Barcelona, RBA, 2010), which is a compilation of some of this author's work published between 1996 and 2010 reflecting his outstanding historiographic, intellectual and political trajectory (these contributions occurred in the Debate Seminar "The Current Spain" at the University of Salamanca in March 2015, attended by the author of the book.)

Professor Juliá, one of the most renowned academics on the current stage of Spanish historiography, is a well-known author in Historiografías, which published an interview with him in Issue number 3, where he tackled topics such as the present situation of Spanish historiography, the influence of Post-modernism in historical writing, and the memory of the Spanish Civil War. Apart from its criticism of the book, Professor Cuesta Fernández's paper has an interesting feature that goes beyond the controversy existing between two historians: it gives a rough idea of the salient debates affecting the public use of the past in Spain. The article addresses a twofold topic: a) how to assess the political and social shifts that have come about in Spain since the $19^{\text {th }}$ century: failure, normality, other options?; b) how the perception of the Spanish political transition has changed today and how this change of memories should affect historians; and c) what and how the role of the current culture of memory ought to concern historiography in general and the appraisal of memory and the history of the Spanish Civil War in particular? This is a paper which will surely not go unnoticed by our readers.

The second of the pieces of "Varia historiográfica", by the Argentine specialist Professor Patricio Iván Pantaleo, has a purpose, in the context of the journal, that is half informative, half interdisciplinary. It forms part of the interest of Historiografías in drawing attention to specialties or areas which are considered to be often relatively minor subjects. The work is entitled, "Mircea Eliade and the History of Religions. Readings and Contributions to a Historiographic Dissemination". In this paper, Professor Pantaleo reviews the main authors belonging to the field of the history of religions (which includes the literature from Latin America), and focuses upon the life and work of the figure who is perhaps its foremost representative: the Romanian Mircea Eliade, an intellectual who, as the author says, was much more than a simple historian of religions. For the sake of argument, we shall retain the following idea in the article, which was coined by Carlo Ginzburg in his comments on the Romanian and can shed light on how complex an intellectual career may be, as well as the play of identities and cultural memories: Eliade's work has an ambivalent nature: he served in the Romanian extreme right during the inter-war period and in the World War II, but was capable of juggling his militancy with Orientalism (he travelled to India and was heavily influenced by its cultures), which led to his interest in the field of the history of religions. Ginzburg makes this comment on Eliade's ambivalence: "the age of simple dichotomies is over". 
The issue ends as usual with the Section of Crítica: ensayos bibliográficos y reseñas. In this case, we have included comments on recent books on Spanish historiography, Hispanism, Epistemology, memory, theory of historiography, and Classical Studies.

\section{Gonzalo Pasamar}

\section{Présentation}

Théories de la culture, temps historique, mémoires politiques et usages publics du passé, identités et constructions narratives : tels sont les thèmes qui composent ce nouveau numéro de Historiografías. Il s'agit de questions dont la place n'est plus à faire dans le débat historiographique international, et la revue n'a cessé de s'en faire l'écho depuis le lancement de son premier numéro, voici exactement cinq ans. Notre dimension globale bénéficie en outre du soutien d'un conseil scientifique qui compte parmi ses membres, à côté de professeurs d'universités espagnols spécialistes de la théorie et de l'étude de l'historiographie, des experts connus exerçant dans des universités américaines, britanniques, françaises et latino-américaines.

Ce numéro est l'occasion d'exprimer notre tristesse suite au décès du Professeur Elpidio Laguna Diaz, membre de notre conseil scientifique, disparu le 25 janvier dernier. C’est à lui que le contenu de ce numéro 11 est dédié. Le professeur Laguna Diaz était un hispaniste apprécié tout particulièrement au sein de la communauté hispanique et portoricaine des États-Unis. Né près de la capitale portoricaine, à San Juan, dans l'État de Rio Piedras, il avait déployé sa carrière de professeur à partir de 1972 au Department of Classical and Modern Languages and Literature de Rutgers, l'Université d'État du New Jersey, sur le campus de la ville de Newark, se spécialisant dans la littérature et l'histoire espagnoles et latino-américaines. Ses nombreux disciples, qui aujourd'hui donnent des cours de langue et de culture hispaniques dans des universités et lycées de ce pays, sont unanimes à l'heure de souligner son énorme dévouement comme enseignant et sa largeur de vue: le professeur Laguna Diaz présentait certaines spécificités qui l'avaient conduit à vouer un intérêt particulier à la théorie des cultures et à la réflexion historiographique.

J'ai eu l'occasion de le rencontrer et d'être généreusement accueilli dans son département par lui et son épouse Asela Rodriguez, directrice (Chair) du département. Je peux donc témoigner de cette impression qu'il laissait à ses élèves : le Professeur Laguna Diaz associait à une vaste culture qui embrassait tant l'histoire de l'Espagne que celles des États-Unis une volonté de défense passionnée du monde hispanique (qui pour lui trouvait son complément dans les études portugaises et luso-brésiliennes), combinée à un intérêt pour la théorie de l'histoire. En fait, ces deux aspects étaient liés, car Elpidio Laguna était un hispaniste militant qui concevait la culture hispanique, unie à la culture lusophone, comme une forme de culture au sens large du terme (idées, croyances, passé, mémoire, opinion publique, etc.). Bon connaisseur de l'Espagne - il avait vécu à Salamanque puis dirigé plusieurs programmes de cours d'été, d'études et d'échanges, depuis Rutgers -, il s'était consacré depuis son poste de professeur à la diffusion de 
l'identité et de la culture hispano-lusophones et de ce qu'il considérait comme leurs principaux véhicules d'expression: l'espagnol et le portugais. Sa défense de la culture hispanique l'avait conduit à s'intéresser à la théorie de la culture et de l'histoire. Dans le numéro 3 de Historiografías (premier semestre 2012, p. 8-25), il avait publié un très important texte d'analyse de théories de la culture, que nous recommandons, intitulé: "Globalización, Civilización, Americanización: cabos sueltos». Il y exposait sa conception de l'hispanisme comme phénomène culturel, montrant l'étendue de ses connaissances.

Ce n’est donc pas un hasard si le professeur Elpidio Laguna faisait aussi partie du Conseil scientifique de "Historia a debate », fondé par le professeur Carlos Barros en 1999 - forum qui a incontestablement réalisé un travail remarquable pour rapprocher les visions de l'histoire dans le champ hispanique (Espagne et Amérique latine), sur la base de son célèbre Manifeste. En outre, Elpidio Laguna fut vice-président de la International Society for the Comparative Study of Civilizations (1998-2004), sous le mandat de Wayne M. Bledsoe, aujourd'hui professeur émérite de la Missouri University of Science and Technology.

La théorie et l'histoire comparée des civilisations, qui remonte à plusieurs décennies, a une origine européenne, comme on peut lire sur le site officiel de la International Society for the Comparative Study of Civilizations, où l'on affirme avec fierté qu'elle fut fondée à Salzbourg en 1961 lors d'une réunion à laquelle avait assisté rien moins que le célèbre historien britannique Arnold J. Toynbee. Mais l'endroit où cette spécialité s'est développée fut les États-Unis à partir des années soixante-dix : d'abord parce que c'est là-bas et pendant cette décennie que ses composantes multiculturelles ont commencé à se diversifier - une fois que la minorité afroaméricaine eut conquis ses droits civils élémentaires ; ensuite parce que c'est dans ses universités que se sont implantés des auteurs qui ont expérimenté la théorie marxiste la plus hétérodoxe comme d'autres théories que l'on pourrait qualifier de postmodernes. Pour le professeur Elpidio Laguna, comme on peut observer dans son article publié par Historiografías, l'étude de la théorie des civilisations était utile pour comprendre les effets de la mondialisation et pour explorer la place de la culture hispanique dans un tel contexte.

Comme nous le disions, le présent numéro de Historiografías embrasse une vaste thématique, un répertoire qui non seulement aborde la théorie des cultures, mais s'étend à l'historiographie et aux mémoires d'un vaste espace géographique et chronologique qui va de l'Espagne à l'Argentine, en passant par le Mexique, et qui couvre des thématiques récentes, comme la Transition, jusqu’à l’histoire médiévale.

Les années soixante-dix et quatre-vingt, une fois achevés les processus de décolonisation, une fois amorcée la régression économique de l'empire soviétique et le libéralisme commençant à bénéficier d'un retour en grâce, on a assisté à un nouveau départ de la théorie des cultures. Ce renouveau, associé à des aspirations mémorielles (ou plus précisément à même d'intégrer la réflexion sur la mémoire) n’a pas cessé. Ces deux décennies ont non seulement été celles de l'apogée des études sur le postmodernisme, grâce, en particulier, aux études de Fredric Jameson (en particulier les années quatre-vingt), mais aussi celles de la première reconsidération des formulations du concept de modernité. 
Le professeur de l’Université du Pays basque (Bilbao), José Javier Diaz Freire, ouvre la rubrique « Histoire et théorie » avec l'article «Tiempos de modernidad, a propósito de Marshall Bergman », où il remet au goût du jour un texte classique, au centre des débats lors des années qui précédèrent la chute du Mur et avant que l'on ne tombe définitivement dans la mondialisation, et dont certains des chapitres remontent aux années soixante-dix. Il s'agit de l'ouvrage du penseur marxiste Marshall $\mathrm{H}$. Berman, professeur de Sciences politiques et d'Urbanisme au City College de New York et décédé il y a trois ans: All that is Solid Melts into the Air. The Experience of Modernity, publié en 1983 et en 1988, et traduit en espagnol cette année.

Berman, peut-être grâce à son marxisme hétérodoxe, fait partie d'une tradition philosophique beaucoup plus large, qui durant le $\mathrm{xx}^{\mathrm{e}}$ siècle a critiqué les concepts hégéliens d'histoire et de temps, ou, dans son cas, le marxisme dit " économiciste " (tradition qui va de Martin Heidegger à Walter Benjamin). Le principal apport de Berman consiste, selon le professeur Diaz Freire, à montrer que l'idée de " modernité » (et par extension celle de "modernisation » et celle de "modernisme ») peut être une notion "liquide ", c'est-à-dire, sujette à un temps hétérogène, ce qui équivaut à lui attribuer une propriété similaire à celle que certains auteurs réclament pour la catégorie de la postmodernité (par exemple Zigmunt Bauman quand il utilise, non sans équivoque, le terme "modernité liquide" pour se référer à ce qui est postmoderne). Comme indique le professeur Diaz Freire, si nous voulons que le concept de modernité ait une valeur pour la recherche en sciences sociales aujourd'hui - « que soit levé l'état de siège » sur ce concept -, il n'est d'autre solution que d'abandonner l'idée d'un temps homogène. Les réponses qu'ont données Perry Anderson et Peter Osborne à Berman ce dernier sous l'influence de la réflexion de Koselleck sur les temporalités -, habilement commentées dans cet article, donnent une bonne idée des possibilités d'actualisation de ces concepts de modernité, de modernisation et de modernisme.

Le reste des articles de ce numéro de Historiografías portent sur la mémoire, sur les identités nationales et leurs récits, en relation avec l'écriture de l’histoire.

Le texte de Diaz Freire laisse la place à celui des professeurs Oscar Fernando Lopez Meraz et Diana Villegas Loeza, qui aborde un thème qui a joué et joue encore un rôle décisif dans les mutations de l'historiographie depuis les années quatre-vingt, celui des identités nationales - avec la référence obligée, faite par les auteurs, aux pionniers Benedict Anderson et Eric J. Hobsbawm. Le texte s’intitule «Discurso científico, profesionalización histórica e didentidad nacional mexicana ». Cette ligne avait déjà été traitée dans Historiografías à propos, par exemple, de la question du «bretonnisme politique » (dans le numéro 5). Dans ce texte, qui se rapporte à l'identité mexicaine, est posée de surcroît la question de la naissance et du développement de la profession d'historien dans ce pays depuis le $\mathrm{XIX}^{\mathrm{e}}$ siècle - bien que la première Histoire $d u$ Mexique, déjà porteuse d'une idée d'identité nationale, fût publiée par le jésuite Francisco Javier Clavijero au XVIII ${ }^{\mathrm{e}}$ siècle. Les auteurs signalent que le processus est étroitement lié à la diffusion du sentiment d'appartenance à cette " communauté imaginaire ", qui réclame futur et passé, comme celui qui correspond à l’idée de nation moderne. Parmi les principaux éléments de la mexicanité, Lopez Meraz et Villegas mettent l'accent sur la figure de l'Indien, qui permet de faire remonter l'histoire du pays jusqu'à des temps préhispaniques. De la sorte, depuis le politique, journaliste, historien 
et leader de l'indépendance Carlos Maria Bustamente, jusqu'aux analyses les plus récentes, la figure de l'Indien demeure le support du stéréotype qu'au XVI ${ }^{\mathrm{e}}$ siècle avait dressé le Franciscain et chroniqueur des Indes Bernardino Sahagún. Pour être évidente, la conséquence que l'on peut tirer d'une telle utilisation de l'Indien n'en est pas moins importante: l'histoire de l'historiographie, des identités et de la mémoire revêt une valeur démythificatrice, et dans ce cas permet de montrer à quel point les sources, loin d'être des fonds neutres et innocents, sont le produit de l'ambiance sociale et culturelle et doivent être traitées comme telles.

Le texte de la professeure argentine María del Mar Solís Carnicer, «El pasado argentino en disputa. Peronismo y antiperonismo en la interpretación de la historia de la provincia de Corrientes ", qui vient en troisième place, nous conduit vers un terrain proche qu'Historiografías a aussi abordé dans des numéros précédents: celui de la guerre des mémoires (dans le numéro 8), celui du rôle des héros dans la construction mémorielle et dans l'historiographie nationale (dans le numéro 10). Le travail de la professeure Solís Carnicer étudie les particularités que présente le débat sur les usages publics du passé dans la province argentine de Corrientes. Cette province périphérique, située au Nord-Est du pays, bordée au Nord par le Paraguay, comptait, indique l'auteure, son propre panthéon des héros de l'Indépendance, et avait été jusqu'à « régionaliser » la figure du Libertador José de San Martín. L’arrivée du péronisme à la fin des années quarante - avec une position de révision de l'histoire argentine et une vision différente de la politique - et la commémoration du centenaire de la mort du Libertador en 1950 mettra ce panthéon sens dessus dessous et changera la figure des héros locaux, qui suscitaient jusqu'alors une unanimité consensuelle. Ce travail offre une vision très complète de l'orientation des études historiques dans cette province mais, comme le signale l'auteure, la guerre mémorielle suscitée par le péronisme n’a rien à voir avec les actions passées de ces grands personnages : elle était plutôt liée aux « intérêts du présent ».

La rubrique « Histoire et théorie » se ferme sur le travail de l'historien galicien Bruno Padín Portela: "Un episodio en la construcción narrativa de la Historia de España: los traidores y la 'pérdida de España' », qui suit la lancée des études sur les identités nationales et les mémoires (la mémoire culturelle, pourrions-nous dire ici). Ce texte examine le stéréotype ou la structure narrative représentée dans un épisode célèbre qui a sa trace dans les Histoires de l'Espagne des siècles durant, depuis l'Histoire générale de l'Espagne du Père Mariana publiée à la fin du $\mathrm{XVI}^{\mathrm{e}}$ siècle, jusqu'à l'encyclopédique Historia de España Menéndez Pidal éditée tout au long du $\mathrm{Xx}^{\mathrm{e}}$ siècle, en passant par celle de Modesto Lafuente au XIX ${ }^{\mathrm{e}}$ : la tradition "gothiciste » qui atribue la disparition du royaume wisigoth de Tolède à la « trahison du comte don Julian » qui, pour venger le viol de sa fille par Rodéric, s'allia avec les Juifs et provoqua la « perte de l'Espagne », selon l'expression consacrée. Afin d'examiner la pertinence et la permanence de ce récit, l'auteur procède à sa « déconstruction » suivant plusieurs lignes qui ne manqueront pas d'intéresser le spécialiste ès historiographie : en premier lieu, les origines de ce récit à partir de l'étude des versions des chroniqueurs et de leurs variantes; en second lieu, sa pertinence initiale à travers deux notions, à savoir, d'un côté, le concept de " trahison » dans le droit romain et dans les codes germaniques et, de l'autre, l’idée du désir sexuel selon le texte contemporain des Étymologies (VII ${ }^{\mathrm{e}}$ siècle) de Saint Isidore. On pourrait ici de nouveau souscrire aux propos de la professeure Solis Carnicer dans son article: ce récit en dit plus sur les vicissitudes de la mémoire 
culturelle et du genre historique au cours des siècles que sur la réalité du phénomène de l'arrivée des Musulmans sur la péninsule ibérique au viII ${ }^{\mathrm{e}}$ siècle. Pour démontrer cela, l'auteur s'arrête aussi sur les écrits des spécialistes de ce phénomène, depuis le grand historien du Royaume visigoth, professeur à Nottingham, Edward A. Thompson, aujourd'hui décédé, jusqu’à des auteurs récents comme Alejandro García Sanjuán, en passant par l'Américain Norman Roth ou les Espagnols Pedro Chalmeta et Luis Agustín García Moreno.

La rubrique «Varia historiográfica » présente cette fois deux articles très différents, bien que reliés par la question des mémoires et des identités. Le premier est celui du professeur Raimundo Cuesta Fernández, et a pour titre « La normalización historiográfica y la pérdida de la inocencia. Reflexiones acerca de algunas tesis del historiador Santos Juliá ». Ce texte est une lecture critique du libre du professeur Santos Juliá, Hoy no es ayer. Ensayos sobre la España del siglo XX (Barcelone, RBA, 2010), qui recueille des écrits publiés entre 1996 et 2010, reflet de la remarquable trajectoire historiographique, intellectuelle et politique. L'intervention avait eu lieu au Séminaire ouvert « L'Espagne actuelle » de l’Université de Salamanque en mars 2015, en présence de l'auteur du livre.

Le professeur Santos Julia, un des historiens les plus éminents du panorama espagnol actuel, est un auteur que nous connaissons dans Historiografías, qui avait publié un entretien avec lui dans le numéro 3, dans lequel il abordait des questions comme la situation actuelle de l'historiographie et de la mémoire de la Guerre civile espagnole. L'article du professeur Cuesta Fernández, au-delà des critiques qu'il formule envers le livre, présente l'intérêt particulier de dépasser la polémique entre deux historiens, donnant une idée assez précise de la teneur des discussions clés qui concernent l'usage public du passé. L'article aborde les thèmes suivants : a) comment mesurer dans leur globalité les changements politiques et sociaux intervenus en Espagne depuis le $\mathrm{XIX}^{\mathrm{e}}$ siècle (échec, normalité, autres solutions)? b) comment s'est modifiée dernièrement la perception de la Transition politique espagnole et comment ce changement des mémoires influe-t-il sur les historiens ? et c) quel rôle joue actuellement la culture de la mémoire et comment joue-t-elle sur l'historiographie en général et sur l'estimation de la mémoire et de l'histoire de la Guerre civile espagnole en particulier ? Voici un article qui ne laissera pas les lecteurs indifférents.

Le second texte de la rubrique "Varia historiográfica", dû au spécialiste argentin, le professeur Patricio Iván Pantaleo, porte, dans le contexte de la revue, une visée à la fois informative et interdisciplinaire. L'un des intérêts de Historiografías est de porter à la connaissance du lecteur des spécialités ou des champs qui demeurent relativement minoritaires. Le travail est intitulé "Mircea Eliade y la historia de las religiones. Lecturas y aportes para una difusión historiográfica ». Dans ce texte, le professeur Pantaleo passe en revue les principaux auteurs du champ de l'histoire des religions (il inclut une bibliographie latino-américaine) pour s'arrêter sur la vie et l'œuvre de l'un de ses principaux représentants : le Roumain Mircea Eliade, une figure intellectuelle qui, comme le dit l'auteur, a dépassé de loin l'historien des religions. De cet article, retenons cette idée qui fut commentée par Carlo Ginzburg dans ses commentaires sur Eliade, et qui montre combien une trajectoire intellectuelle peut être complexe, tout comme le jeu des identités et mémoires culturelles : son œuvre a un caractère ambivalent. Eliade avait milité dans l'extrême-droite roumaine dans l'entre- 
deux-guerres et pendant la Seconde Guerre mondiale, mais il fut capable de rendre compatible cette activité militante avec l'orientalisme (il avait fait un voyage en Inde, dont les cultures l'avaient marqué), qui le mena sur le terrain de l'histoire des religions. Et Ginzburg de faire ce commentaire au sujet de cette ambivalence : " C'en est fini de l'époque des simples dichotomies ».

Le numéro s'achève comme d'habitude sur la rubrique Crítica: ensayos bibliográficos y reseñas. Dans le cas présent, nous avons inclus des commentaires de livres récents sur l’historiographie espagnole, l'hispanisme, l'Épistémologie, la mémoire, la théorie de l’historiographie et des études sur l’Antiquité.

Gonzalo Pasamar 